\title{
TRAJNOSTNI PROSTORSKI RAZVOJ R SLOVENIJE: OD CENTRALNOSTI KRAJEV K OMREŽJU KRAJEV
}

Temeljni raziskovalni projekt izhaja iz teoretskih konceptualizacij procesov globalizacije, teženj po trajnostnem razvoju ter racionalizaciji slovenskega prostorskega sistema. Tako globalizacijski procesi kot evropski integracijski procesi "ogrožajo" uveljavljene nacionalne prostorske sisteme, ki so s svojo centralistično hierarhijo ovira integracijskim procesom in uvajanju nove trajnostne razvojne paradigme. Na osnovi spoznanj o opisanih globalnih družbeno-prostorskih procesih postavljamo temeljno raziskovalno hipotezo, da je za uveljavitev novih razvojnih paradigem potreben prehod iz centralističnega in hierarhiziranega prostorskega sistema, ki temelji na logiki centralnosti krajev, v nehierarhični omrežni prostorski sistem. Če analiziramo prostorski sistem Slovenije, ugotavljamo, da se v zadnjem desetletju le-ta centralizira z zgoščanjem odločanja in dogajanja na nacionalni ravni. Ta model družbeno-prostorske organizacije, ki na ravni prostorskega sistema ohranja staro hierarhično logiko, lahko sicer razumemo kot preventivno upravno-sistemsko odločitev v luči osamosvojitvenih procesov, a se hkrati moramo zavedati, da je dolgoročno razvojno gledano eden temeljnih generatorjev prostorsko neuravnoteženega razvoja RS oz. generator nove postmoderne perifernosti oz. izključenosti in zagat pri operacionalizaciji načel trajnostnega razvoja. To se kaže $\mathrm{v}$ poglabljanju medregionalnih razlik glede kvalitete življenja med osrednjo in obmejnimi, perifernimi regijami.Ob tem pa proces širjenja poselitvenih površin $\mathrm{v}$ obliki razpršene gradnje predstavlja enega najpomembnejših problemov, povezanih z razvojem mest $v$ Evropi.

Temeljni namen raziskovalnega projekta je odgovoriti na vprašanje, kakšne spremembe prostorskega sistema bi omogočile, da bi dosegli sinergijo relativno dobre informacijske razvitosti, raznovrstnih prostorskih in okoljskih kakovosti ter razvojnih potencialov RS. Problematika se povezuje $\mathrm{z}$ novo prostorsko zakonodajo in pripravo novih prostorskih dokumentov, še posebej pa njihovo izvedbo. $V$ aplikativnem delu je vključen vzorčni primer Ljubljanske urbane regije, s prikazom trajnostnih vzorcev razvoja in možnostmi njihove realizacije s pomočjo instrumentov prostorske politike.

Nosilec naloge je Drago Kos, FDV Univerze v Ljubljani, soizvajalki pa Mojca Šašek Divjak, Urbanistični inštitut RS in Nataša Pichler-Milanovič, FF Univerze v Ljubljani.

Nataša Pichler-Milanović 